\title{
EXAMINATION OF MORPHOLOGY AND SURFACE STRUCTURE OF COCCI LACTIC ACID BACTERIA BY SCANNING ELECTRON MICROSCOPE AND IMAGE ANALYSIS. \\ Ashwak.A.hassan ${ }^{\text {a }}$;Hoda.M.elzeini ${ }^{\mathrm{b}}$;N.F.Nasr.and Awad A.awad ${ }^{\text {d. }}$ ${ }^{a}$ Dairy science department ,Faculty of agriculture,Cairo university , ${ }^{b}$ Dairy science department ,Faculty of agriculture,Cairo university, 'Department of Agricultral microbiology ,Faculty of agriculture,Cairo university, \\ ${ }^{d}$ Dairy science department ,Faculty of agriculture,Cairo university
}

\begin{abstract}
Lactic acid bacteria ( $L A B$ ) widely distributed in nature and play an important role in much food fermentation. Bacteria cell morphology is useful and valuable characteristics used in the classification and identification of bacteria. Therefore, cell morphological shape and size of six strains of cocci LAB were studied in broth and milk media using scanning electron microscope (SEM) and image analysis technique. Results indicated that, Pediococcus acidilactica was the smallest strain in size and Streptococcus thermophilus was smaller than Enterococcus and lactococcus strains. Except Pediococcus acidilactica, cells of other strains were generally smaller in size when grown in milk media than in broth media. Cells of cocci LAB were not perfect spherical cells. In conclusion, cell shape and size parameters can be used for identification and classification of cocci $L A B$ with determination of define standard conditions for growth.
\end{abstract}

Keywords: Cocci LAB, SEM, Image analysis, Cell size

\section{INTRODUCTION}

Bacteria are very small living organisms have size rang 1-5 $\mu \mathrm{m}$. Lactic acid bacteria (LAB) widely distributed in nature and play an important role in many foods and feed fermentation (Wood and Holzapfel, 1995). The gram positive coccus group of $L A B$ has spherical cell shape ranging in diameter from 0.5-3.5 $\mu \mathrm{m}$, which occur singly or in pairs, chains and tetrads (Collins et al., 1993).

Bacterial cell size and shape are still useful and valuable morphological characteristic used in the classification and identification of bacteria because morphological structural features are usually genetically stable and easy to study and analyze (Prescot et al., 1993). For a quick examination of the bacterial cell, the scanning electron microscope (SEM) can be used for the study of the cell surface and its properties. In addition to, image analysis techniques can be used to define parameters such as size, shape, diameter, surface area and volume of the object which are recognized in an image (Schleifer ,2009).

The current study aim to get a new specific information and data base about the small differences in bacterial cell morphological shape and size of cocci LAB using advanced techniques such as SEM and Image analysis software techniques, which enable to determine different 
morphological parameters of cocci LAB in both milk and MRS culture media that could be used for their identification and classification.

\section{MATERIALS AND METHODS}

\section{Bacterial strains and their Growth conditions}

Pure bacterial culture of Enterococcus faecalis (780N), Lactococcus lactis subsp.lactis $(774 \mathrm{~N})$, Lactococcus lactis subsp.cremoris $(764 \mathrm{~N})$, Streptococcus thermophilus $(779 \mathrm{~N})$ and Enterococcus faecium(744N) were obtained from Faculty of Agriculture Alexandria University while, Pediococcus acidilactic(EMCC1690) strain was obtained from Cairo Mircen Microbiological Resources Center at Ain-Shams university. Culture were grown aerobically on $\mathrm{M} 17 \mathrm{broth}(\mathrm{pH} 7.15)$ and reserved at $2-5^{\circ} \mathrm{C}$.

\section{Manufacture of fermented milk}

Low heat skim milk powder (mefad, Egypt) was reconstituted to $11 \%$ $(\mathrm{w} / \mathrm{v})$, sterilized at $115^{\circ} \mathrm{c}$ for $7 \mathrm{~min}$, cooled and kept in the refrigerator overnight. The following day, the reconstituted milk was warmed to $30^{\circ} \mathrm{C}$ and inoculated with $3 \%(\mathrm{v} / \mathrm{v})$ of L.A.B strains. Inoculated milk was incubated at 32 ${ }^{\circ} \mathrm{c}$ for strains until a pH value reached 4.7. Fermented milk was microscopically examined and then kept at $5^{\circ} \mathrm{C}$ for $24 \mathrm{hrs}$.

\section{Sample preparation for scanning electron microscope}

A fundamental and unique characteristic of the scanning electron microscope is its imaging system . Cells at the desired growth stage were obtained after the third subculture in broth media and centrifugation at $3000 \mathrm{rpm}$ for $1 \mathrm{~min}$, addition of Glutalaldahyde $3 \%$ and washed with phosphate buffer0.1 mol..$^{-1} \mathrm{pH} 7.2$ for $10 \mathrm{~min}$. Then dehydrated through a graded ethanol series $5 \mathrm{~min}$ each at $10 \%, 20 \%, 30 \%, 40 \%, 50 \%, 60 \%, 70 \%$, $80 \%, 90 \%$, and 100 for $5 \mathrm{~min}$ at $100 \%$; phosphate buffer $(\mathrm{pH} 7.2)$. For fermented milk at the end of coagulation period one $\mathrm{ml}$ of each sample was taken and diluted $(1: 10, \mathrm{v} / \mathrm{v})$ with $0.2 \%(\mathrm{w} / \mathrm{v})$ EDTA to precipitate the casein micelle. The sample were then examined and photographed .Because the method relies on the accuracy of measurements, there for care was taken to use the microscope at the same viewing angle constantly.

Image analysis

For image analysis we used SPIP program 6.0.6 (BETA,Denmark)which enables the user to manipulate lateral calibration and unit cell detection to account for magnification differences in each image $s$. After calibration of the program according to the scale bar on the micrographs, cells were magnified for better definition of the cell edges; the cells were then measured by moving the pointer from one cell edge to the other side edge. Detection and quantification of bacterial cell was done using the polygone measure shape. The program was keeping the measurements in memory and calculating some statistical values. Several morphological and geometrical parameters such as (Diameter, Area, Length , Breadth, , Perimeter, Roundness, compactness, solidity, Hardness, Roughness and wall thickness) were obtained by system as follows in figure 1 . 
Area

The Area is calculated from the shapes periphery, i.e. the closed polygon that surrounds the feature. The area is calculated using:

Diameter

The diameter (or Heywood diameter) is expressed as the diameter of a circle having an area equivalent to the shape's are Length

Length is defined as the longest cord along the angle $\theta$ given by the moment's axis to the x-axis. In other words, if we rotated the shape so that the moment's axis becomes parallel to the x-axis, then Length is the extension of the bounding rectangle in the horizontal direction

\section{Breadth}

Breadth (or width) is defined as the longest cord perpendicular to the angle $\theta$ given by the moments axis to the $x$-axis. In other words, if the Shape was rotated so that the moment's axis becomes parallel to the $x$-axis, then Breadth is the extension of the bounding rectangle in the vertical direction.

Perimeter:For Polygon shapes the perimeter is calculated from the shape's contour

Roundness:Roundness describes the shape's resemblance to a circle. The roundness factor of a shape will approach 1.0 the closer the Shape resembles a circle.

Compactness:Compactness is a measure expressing how compact a feature is.

Solidity: Solidity is a measure describing the resemblance of the shape's area with it's convex area.

\section{Statistical Analysis}

The two-way statistical analysis of variance (ANOVA), 4 factor factorial, mean separation and correlation required subprogram of MSTAT microcomputer statistical program(ver.4c,1989) to evaluate the morphological parameters of cocci lactic acid bacteria. The effect of lactic acid bacteria strains and type of media were analyzed using analysis of variance and the student "t" test.

\section{RESULTS AND DISCUSSION}

Scanning Electron Microscopy (SEM) techniques have recently been applied to study the bacterial shapes. To understand the important role of bacterial shapes in taxonomy, we investigated their native shapes using SEM. The Lactic acid bacteria physical properties obtained from Cairo Mircen Microbiology Resources Center at Ain-Shams University were photographed and representative images are shown in Fig. 2. Topographical images reveal spherical or pseudo-spherical structures with height profiles. Images produced from scans are analyzed using SPIP software for the SEM images. However, most of the functions in different software are similar and thus the results are comparable. The bright and dark areas in the images correspond to peaks and troughs in the objects. Commonly, different scales are used in the vertical and horizontal axes. There are many offline operations for getting 
object properties. For example, sectional profile analysis is used to measure the depth, height, and width of specimens. Roughness analysis is performed over an entire image or a selected part of the image to describe the surface status of the bacteria. The principle of force spectroscopy is based on force distance curve measurement. The fine structure of the bacteria was observable with SEM. It is typical, when using SEM to observe a 3dimensional spherical object such as bacteria that the central region of the image is darker than the periphery. This is not indicative of a change in electron density but represents more scattering opportunities being present when the thickness of the sample traversed by the light density is greater. When viewing an entire cell, the large number of individual components being visualized depending on the cell size (Victoria et al,2013). This allowed determining structural arrangements in peripheral regions where individual planes of components could be examined and using this information to make general conclusions about the overall structure of the cells.

Fig (1) Micrograph of Enterococcus faecium, Enterococcus faecalius, and Lactococcus cremoris (A, C, E) in broth media and (B, D, F) in milk. Micrograph of Streptococcus thermophilus, Lactococcus lactis , and Pediococcus acidilactica (G, I, K) in 1. Bacterial size broth media and $(H, J, L)$ in milk

We investigated that Bacterial cells had almost spherical structure with a wide range of diameters. Table (1) shows the maximum and minimum diameters for different cocci bacteria with standard deviations. Cocci group 
has spherical cell ranging in diameter from 0.79-1.51 $\mu \mathrm{m}$. Hardie , 1986 stated that coccus group has spherical cell ranging in diameter from 0.5-2 $\mu \mathrm{m}$ which is wider than what was obtained in this work.

Table 1. Maximum, minimum and average Diameter (um) of cocci lactic acid bacteria

\begin{tabular}{|c|c|c|c|c|c|c|c|c|c|c|c|c|}
\hline \multirow{2}{*}{$\begin{array}{l}\text { Diameter } \\
\text { (um) }\end{array}$} & \multicolumn{2}{|c|}{ En.faecalius } & \multicolumn{2}{|c|}{ En.faecium } & \multicolumn{2}{|c|}{$\begin{array}{c}\text { St.thermo } \\
\text { philus }\end{array}$} & \multicolumn{2}{|c|}{ L.s lactis } & \multicolumn{2}{|c|}{ L.cremoris } & \multicolumn{2}{|c|}{ Pedi.acidilact } \\
\hline & $B \mathbf{m}^{1}$ & $\mathrm{Mm}^{2}$ & B m & Mm & $\mathrm{B} \mathrm{m}$ & $\mathrm{Mm}$ & B m & Mm & B m & $\mathrm{Mm}$ & B m & $\mathrm{Mm}$ \\
\hline Maximum & 1.50 & 1.31 & 1.43 & 1.30 & 1.33 & 1.37 & 1.43 & 1.49 & 1.51 & 1.11 & 0.99 & 1.03 \\
\hline Minimum & 1.28 & 1.09 & 1.30 & 1.26 & 1.08 & 0.93 & 1.19 & 1.13 & 1.22 & 0.87 & 0.79 & 0.91 \\
\hline Mean & 1.38 & 1.22 & 1.35 & 1.28 & 1.17 & 1.11 & 1.33 & 1.30 & 1.34 & 0.93 & 0.91 & 0.96 \\
\hline Sd & 0.08 & 0.08 & 0.06 & 0.02 & 0.08 & 0.14 & 0.07 & 0.14 & 0.10 & 0.09 & 0.07 & 0.06 \\
\hline
\end{tabular}

$\mathrm{Mm}^{2}$ : Milk media ,LSD at $(\alpha=0.05)=0.0799$, Coefficient of Variation: $7.63 \%$

he highest cells diameter was obtained as 1.515 um for Lactococcus cremoris, while the smallest ones as 0.79 um for Pediococcus acidilacict. The bacterial cell diameters' averages were $1.38 \mathrm{um}, 1.35 \mathrm{um}, 1.17 \mathrm{um}, 1.33 \mathrm{um}$, $1.347 \mathrm{um}$ and $0.91 \mathrm{um}$ in broth media for En.faecalius, En.faecium, St.thermophilus, L.lactis, L.cremoris and Pedi.acidilact, respectively. In milk media, the bacterial cell diameters' averages were 1.22um, 1.28um, $1.11 \mathrm{um}$, $1.30 \mathrm{um}, \quad 0.93 \mathrm{um}$ and $0.96 \mathrm{um}$ for En.faecalius, En.faecium, St.thermophilus, L.lactis, L.cremoris and Pedi.acidilact, respectively. Statistical significant differences $(L S D=0.0799)$ were found within bacterial cell diameters means as a function of bacterial species and type of media (a $=0.05$ ). No significant differences were found between Lc. cremoris, En. faecium and Lc. Lactis in diameter. Bacterial species and type of media factors caused significant differences in cells diameters and the interaction between the two factors also significantly affected the bacterial cells diameters as confirmed by $\mathrm{F}$ test while Student $\mathrm{T}$ test confirmed significant effect of bacterial species and type of media

By comparing the data of the three cocci genera, it becomes evident that there is a significant difference in the size of their cells. The Streptococcus thermophilus strains seem to be the biggest, with the Enterococci strains being smaller, whereas those of the Lactococcus lactis subsp lactis being the smallest. This was also verified by applying the ANOVA (analysis of variance) statistical method to the mean values of the sizes of the different strains of each different genus

\section{Bacterial cells breadth}

The structure of bacterial cells showed imperfect spheres which could have length and width as imperfect rectangles(Table2). 
Table 2 . Maximum, minimum and average breadth (um) of cocci lactic acid bacteria

\begin{tabular}{|c|c|c|c|c|c|c|c|c|c|c|c|c|}
\hline \multirow{2}{*}{$\begin{array}{c}\text { Breadth } \\
\text { (um) }\end{array}$} & \multicolumn{2}{|c|}{ En.faecalius } & \multicolumn{2}{|c|}{ En.faecium } & \multicolumn{2}{|c|}{ St.thermophilus } & \multicolumn{2}{|c|}{ L. lactis } & \multicolumn{2}{|c|}{ L.cremoris } & \multicolumn{2}{|c|}{ Pedi.acidilact } \\
\hline & $\mathrm{Bm}^{1}$ & $\mathrm{Mm}^{2}$ & B m & $\mathrm{Mm}$ & B m & $\mathrm{Mm}$ & $\mathrm{Bm}$ & M & $\mathrm{Bm}$ & MB & $\mathrm{Bm}$ & $\mathbf{M m}$ \\
\hline Maximum & 1.43 & 1.31 & 1.23 & 1.14 & 1.05 & 1.30 & 1.35 & 1.44 & 1.47 & 1.13 & 0.97 & 0.91 \\
\hline Minimum & 1.06 & 1.09 & 1.04 & 0.91 & 0.88 & 0.78 & 1.08 & 1.04 & 1.04 & 0.74 & 0.62 & 0.83 \\
\hline Mean & 1.20 & 1.22 & 1.11 & 1.05 & 0.98 & 0.98 & 1.20 & 1.17 & 1.16 & 0.81 & 0.73 & 0.87 \\
\hline Sd & 0.12 & 0.08 & 0.08 & 0.09 & 0.06 & 0.15 & 0.08 & 0.15 & 0.13 & 0.08 & 0.10 & 0.03 \\
\hline
\end{tabular}

$\mathrm{B} \mathrm{m}^{1}$ : Broth media $\mathrm{Mm}^{2}$ : Milk media LSD $=0.075$,Coefficient of Variation: $10.63 \%$

The averages of bacterial cells width along with standard deviation for different species are shown in Table 2. The highest widths was found with L.cremoris (1.47 um) for broth media and L.lactis (1.44 um) for milk media, while, the least breadths were found with Pediacidilact (0.62 um) in broth media and L.cremoris $(0.74 \mathrm{um})$ in milk media. However, an increase in the degree of bacterial cells elongation is believed to be an indicator of bacterial cells distortion. While, no significant differences in breadth were found among En.faecalius, En.faecium and L.lactis at $\alpha=0.05$ in broth media, it differed significantly within the two media $(\mathrm{LSD}=0.075)$ in all species . With species variation, significant $(p<0.001)$ influences were recognized on the width $(P<0.001)$. Additionally, media type and the interaction between the two factors (AB) significantly affected the bacterial cells width $(P<0.05$ and $P<0.01$, respectively).

\section{Bacterial cells length}

Bacterial cells lengths were determined from the data. The measured maximum and minimum length values measured by SPIP software of different species of lactic acid bacteria are presented in Table 3.

Table 3 . Maximum, minimum and average length (um) of cocci lactic acid bacteria

\begin{tabular}{|c|c|c|c|c|c|c|c|c|c|c|c|c|}
\hline \multirow{2}{*}{$\begin{array}{l}\text { Length } \\
\text { (um) }\end{array}$} & \multicolumn{2}{|c|}{ En.faecalius } & \multicolumn{2}{|c|}{ En.faecium } & \multicolumn{2}{|c|}{ St.thermophilus } & \multicolumn{2}{|c|}{ L. lactis } & \multicolumn{2}{|c|}{ L.cremoris } & \multicolumn{2}{|c|}{ Pedi.acidilact } \\
\hline & B m ${ }^{1}$ & $\mathrm{Mm}^{2}$ & B m & Mm & B m & Mm & B m & Mm & B m & Mm & $\mathrm{Bm}$ & Mm \\
\hline Maximum & 1.80 & 1.69 & 1.83 & 1.87 & 1.67 & 1.65 & 1.68 & 1.72 & 1.85 & 1.28 & 1.26 & 1.19 \\
\hline Minimum & 1.53 & 1.33 & 1.53 & 1.43 & 1.29 & 1.08 & 1.31 & 1.31 & 1.41 & 0.91 & 0.95 & 0.97 \\
\hline Mean & 1.63 & 1.52 & 1.69 & 1.57 & 1.47 & 1.30 & 1.50 & 1.51 & 1.59 & 1.07 & 1.07 & 1.08 \\
\hline Sd & 0.10 & 0.14 & 0.13 & 0.20 & 0.13 & 0.18 & 0.12 & 0.15 & 0.12 & 0.13 & 0.10 & 0.11 \\
\hline
\end{tabular}

$\mathrm{B} \mathrm{m}^{1}$ : Broth media $\mathrm{Mm}^{2}$ : Milk media, $\mathrm{LSD}=0.119$, Coefficient of Variation: $9.74 \%$

With L.cremoris (1.85 um) for broth media and En.faecium (1.87 um) for milk media, while the least lengths were found with Pediacidilact (0.95 um) in broth media (Karna1,2007) and L.cremoris (0.91 um) in milk media. As so far, the same bacteria showed the same minimum values for breadths (Table 2) . Within treatments, the media caused insignificant differences for En.faecalius and Pedi.acidilact lengths $(\mathrm{LSD}=0.119)$. Additionally, there were significant effect in length within species of bacteria . Negative correlations were found between bacterial species $(-0.673)$ and type of media used for growing the bacteria $(-0.320)$. Bacterial species $(P<0.001)$, type of media $(P<0.01)$ used for growing the bacteria and the interaction between the two factors $(P<0.05)$ influenced the bacterial lengths while Student $T$ test showed 
also inverse relationships between bacterial length and both variables with $R^{2}$ $=0.747$.

1. Bacterial cells perimeter

Table 4. Maximum, minimum and average perimeter (um) of cocci lactic acid bacteria

\begin{tabular}{|c|c|c|c|c|c|c|c|c|c|c|c|}
\hline \multirow{2}{*}{$\begin{array}{l}\text { Diameter } \\
\text { (um) }\end{array}$} & En.faecalius & \multicolumn{2}{|c|}{ En.faecium } & \multicolumn{2}{|c|}{ St.thermophilus } & \multicolumn{2}{|c|}{ L. lactis } & \multicolumn{2}{|c|}{ L.cremoris } & \multicolumn{2}{|c|}{ Pedi.acidilact } \\
\hline & & B m & & B m & $\mathrm{Mm}$ & $\mathrm{B} \mathrm{m}$ & $\mathrm{Mm}$ & $\mathrm{B} \mathrm{m}$ & $\mathrm{Mm}$ & & $\mathrm{Mm}$ \\
\hline Maximum & 5.195 .20 & 5.18 & 4.50 & 4.60 & 5.20 & 5.54 & 5.08 & 5.19 & 3.54 & 3.24 & 3.80 \\
\hline & 4.1 & 4.1 & 4.04 & 3.4 & 3.02 & 3.76 & & 4.07 & 2.74 & & \\
\hline & 4.6 & 4.5 & 4.17 & 3.9 & 3.7 & 4.53 & 4.45 & 4.70 & 2.98 & & \\
\hline & $0.38 \quad 0.54$ & 0.46 & 0.22 & 0.39 & 0.67 & 0.60 & 0.38 & 0.38 & 0.31 & 0.19 & 0.43 \\
\hline
\end{tabular}

B $^{1}$ : Broth media $\quad$ Mm $^{2}$ : Milk media LSD $=0.381$, Coefficient of Variation: $10.59 \%$

Wide perimeter ranges from 5.54 for L.Lactis to 2.69 um for Pediacidilact with an average from 4.70 um for L.cremoris in broth media to 2.98 um for the same organism but in milk media .

Table 4 showed the perimeters of lactic acid bacterial species as a function of species difference and type of media used for growing the bacteria. Perimeter of En.faecium didn't differ from Lc. Lactis in milk media ( $L S D=0.381$ ). The same results were found with L.cremoris in milk medium and Pedi.acidilact in broth and milk media at $\alpha-0.05$. Significant influence for perimeter was found $(P<0.001)$ as a function of bacterial species, type of media $(P<0.01)$ the bacteria grown in and the interaction $(P<0.05)$ between both factors on perimeter of bacterial cells of different species. Negative low correlations were found between lactic acid bacterial cells perimeters and both bacterial species (-0.592) and growing media type (-0.337). Additionally, regression analysis $T$ test indicated significant differences in perimeters induced by bacterial species $(P<0.001)$ and type of growing media $(P<0.05)$

5- Bacterial cells surface area

The maximum area was obtained for L.cremoris $\left(1.80 \mathrm{um}^{2}\right)$ in broth media, while Pedi.acidilact had the minimum $\left(0.49 \mathrm{um}^{2}\right)$ area. The same trend was observed with diameter data (Table 5).

Table 5. Maximum, minimum and average Area $\left(u^{2}\right)$ of cocci lactic acid bacteria

\begin{tabular}{|c|c|c|c|c|c|c|c|c|c|c|c|c|}
\hline \multirow[t]{2}{*}{$\begin{array}{l}\text { Area } \\
\left(u^{2}\right)\end{array}$} & \multicolumn{2}{|c|}{ En.faecalius } & \multicolumn{2}{|c|}{ En.faecium } & \multicolumn{2}{|c|}{$\begin{array}{c}\text { St. } \\
\text { thermophilus }\end{array}$} & \multicolumn{2}{|c|}{ L.s lactis } & \multicolumn{2}{|c|}{ L.cremoris } & \multicolumn{2}{|c|}{ Pedi.acidilact } \\
\hline & $B \mathrm{~m}^{1}$ & $\mathrm{Mm}^{2}$ & B m & Mm & $\mathrm{B} \mathbf{m}$ & $\mathrm{Mm}$ & B m & Mm & B m & Mm & B m & Mm \\
\hline Maximum & 1.78 & 1.35 & 1.60 & 1.34 & 1.39 & 1.48 & 1.62 & 1.75 & 1.80 & 0.96 & 0.78 & 0.83 \\
\hline Minimum & 1.29 & 0.93 & 1.33 & 1.25 & 0.92 & 0.69 & 1.11 & 1.0 & 1.17 & 0.59 & 0.49 & 0.6 \\
\hline Mean & 1.50 & 1.17 & 1.44 & 1.28 & 1.08 & 0.99 & 1.40 & 1.34 & 1.43 & 0.69 & 0.65 & 0.73 \\
\hline Sd & 0.19 & 0.15 & 0.13 & 0.04 & 0.15 & 0.26 & 0.16 & 0.29 & 0.22 & 0.15 & 0.11 & 0.09 \\
\hline
\end{tabular}

$\mathrm{B} \mathrm{m}^{1}$ : Broth media $\mathrm{Mm}^{2}$ : Milk media , LSD $=0.146$, Coefficient of variation $=3.63 \%$.

The bacterial cell areas' averages were 1.50, 1.44, 1.08, 1.40, 1.43 and $0.65 \mathrm{um}^{2}$ in broth media for En.faecalius, En.faecium, St.thermophilus, L.s lactis, L.cremoris and Pedi.acidilact, respectively. For milk media, the average areas were $1.17,1.28,0.99,1.34,0.69$ and $0.73 u^{2}$ for 
En.faecalius, En.faecium, St.thermophilus, L.s lactis, L.cremoris and Pedi.acidilact, respectively.

Bacterial cells surface areas were significantly $(P<0.001)$ influenced by the species variation and type of media used for growing the bacteria. Moreover, the interaction between the statistical factors significantly $(P<0.001)$ affected the surface areas of the bacteria. The species, media type and their interaction affected significantly $(P<0.001)$ the area of bacterial cells of. However, this parameter were different $(\alpha=0.05)$ within species and media type $(\mathrm{LSD}=0.1459)$. Moreover, Student $\mathrm{T}$ test confirmed the significancy of bacterial cells species and media type $(P<0.001$ and $P<0.01$, respectively) but Within treatments of En.faecium, L. lactis, and L.cremoris had no significant differences at $\alpha=0.05$.

\section{6- Bacterial cells surface volume}

Table6. Maximum, minimum and average Volume of cocci lactic acid bacteria

\begin{tabular}{|c|c|c|c|c|c|c|c|c|c|c|c|c|}
\hline \multirow{2}{*}{$\begin{array}{l}\text { Volume } \\
\left(\mathrm{um}^{3}\right)\end{array}$} & \multicolumn{2}{|c|}{ En.faecalius } & \multicolumn{2}{|c|}{ En.faecium } & \multicolumn{2}{|c|}{$\begin{array}{c}\text { St. } \\
\text { thermophilus }\end{array}$} & \multicolumn{2}{|c|}{ L.s lactis } & \multicolumn{2}{|c|}{ L.cremoris } & \multicolumn{2}{|c|}{ Pedi.acidilact } \\
\hline & $B \mathbf{m}^{1}$ & $\mathrm{Mm}^{2}$ & B m & Mm & $\mathrm{B} \mathrm{m}$ & Mm & B m & Mm & B m & Mm & B m & Mm \\
\hline Maximum & 1.42 & 1.18 & 1.53 & 1.17 & 0.89 & 1.36 & 1.55 & 0.94 & 1.82 & 0.71 & 0.50 & 0.57 \\
\hline Minimum & 1.13 & 0.89 & 1.18 & 1.06 & 0.77 & 0.54 & 1.20 & 0.77 & 1.03 & 0.38 & 0.26 & 0.41 \\
\hline Mean & 1.28 & 1.05 & 1.36 & 1.11 & 0.82 & 1.06 & 1.37 & 0.84 & 1.70 & 0.49 & 0.37 & 0.50 \\
\hline Sd & 0.14 & 0.14 & 0.17 & 0.05 & 0.06 & 0.45 & 0.17 & 0.09 & 0.40 & 0.19 & 0.12 & 0.08 \\
\hline
\end{tabular}

$\mathrm{B} \mathrm{m}^{1}$ : Broth media $\mathrm{Mm}^{2}$ : Milk media , LSD=0.179, Coefficient of variation $=21.73 \%$.

The smallest bacterial cells volume was recognized with Pediacidilact $\left(0.26 \mathrm{um}^{3}\right)$ in broth media (Table 6). L.cremoris scored the highest volume value $\left(1.82 \mathrm{um}^{3}\right)$ in broth media also. The highest mean was registered for L.cremoris $(1.70 \pm 0.40)$.

All strains differed significantly within treatments (LSD $=0.178$ at 0.05 a level.) except for L.cremoris in milk medium and Pedi.acidilact in both media .

Volume of the bacteria was affected significantly $(P<0.01)$ by species variation. On the other hand, type of media did not affect bacterial volume $(P>0.01)$, while, the interaction between the two factors significantly $(P<0.05)$ altered the volume. Multi-regression analysis of volume of cocci lactic acid bacteria species grown in broth and milk media indicated that, Student $T$ test confirmed the significant influence of species variation $(P<0.001)$ and type of medium the bacteria grown in $(P<0.01)$ on the cell volume.

\section{7- Bacterial cells roundness}

Roundness in table 7 was measured through the 2 dimension image analysis. The maximum roundness for bacterial samples was 0.959 for Pediacidilact in broth medium and minimum was 0.489 for En.faecium in milk medium with an average between $0.639 \pm 0.058$ to $0.805 \pm 0.078$. 
Table 7. Maximum, minimum and average Roundness of cocci lactic acid bacteria

\begin{tabular}{|c|c|c|c|c|c|c|c|c|c|c|c|c|}
\hline \multirow[t]{2}{*}{ Roundness } & \multicolumn{2}{|c|}{ En.faecalius } & \multicolumn{2}{|c|}{ En.faecium } & \multicolumn{2}{|c|}{$\begin{array}{c}\text { St.thermophi } \\
\text { Ius }\end{array}$} & \multicolumn{2}{|c|}{ L.s lactis } & \multicolumn{2}{|c|}{ L.cremoris } & \multicolumn{2}{|c|}{ Pedi.acidilact } \\
\hline & $B \mathrm{~m}^{1}$ & $\mathrm{Mm}^{2}$ & B m & Mm & B m & Mm & B m & Mm & B m & Mm & B m & Mm \\
\hline Maximum & 0.908 & 0.953 & 0.716 & 0.797 & 0.709 & 0.883 & 0.956 & 0.875 & 0.953 & 0.909 & 0.959 & 0.894 \\
\hline Minimum & 0.600 & 0.536 & 0.568 & 0.489 & 0.549 & 0.625 & 0.663 & 0.516 & 0.607 & 0.692 & 0.607 & 0.708 \\
\hline Mean & 0.715 & 0.657 & 0.645 & 0.679 & 0.639 & 0.735 & 0.796 & 0.736 & 0.722 & 0.767 & 0.733 & 0.805 \\
\hline Sd & 0.095 & 0.132 & 0.061 & 0.133 & 0.058 & 0.071 & 0.094 & 0.084 & 0.107 & 0.087 & 0.109 & 0.078 \\
\hline
\end{tabular}

Table 7 shows the roundness of bacterial cells for different species of cocci lactic acid bacteria, bacterial species grown in different media showed more cells far away from being a perfect circle (0.639) as found for St.thermophilus in broth medium which indicated irregular circles. St.thermophilus in milk media (0.735), L. lactis in broth and milk media (0.796, 0.736, respectively), L.cremoris in broth and milk media $(0.722,0.767$, respectively) and Pediacidilact in milk media (0.805) had close to circle shapes, However, non significant differences were found in roundness as affected by lactic acid species or type of media used for growing the bacteria $(P>0.01)$.

\section{8- Bacterial cells solidity}

Solidity is a measure describing the resemblance of the shapes' areas with their convex area. All cocci lactic acid bacteria convex area matched their shape's area with the least value of 0.908 (Table 8)

Table 8. Maximum, minimum and average solidity of cocci lactic acid bacteria

\begin{tabular}{|c|c|c|c|c|c|c|c|c|c|c|c|c|}
\hline \multirow[t]{2}{*}{ soldity } & \multicolumn{2}{|c|}{ En.faecalius } & \multicolumn{2}{|c|}{ En.faecium } & \multicolumn{2}{|c|}{ St.thermophilus } & \multicolumn{2}{|c|}{ L.s lactis } & \multicolumn{2}{|c|}{ L.cremoris } & \multicolumn{2}{|c|}{ Pedi.acidilact } \\
\hline & $B \mathbf{~ m}^{1}$ & $\mathrm{Mm}^{2}$ & B m & $\mathrm{Mm}$ & B m & Mm & B m & Mm & B m & $\mathrm{Mm}$ & B m & Mm \\
\hline Maximum & 1.000 & 1.000 & 1.000 & 1.000 & 1.000 & 1.000 & 1.000 & 1.000 & 0.986 & 1.00 & 1.000 & 1.000 \\
\hline Minimum & 0.908 & 0.941 & 0.963 & 1.000 & 0.944 & 0.932 & 0.939 & 0.945 & 0.923 & 1.00 & 0.919 & 0.946 \\
\hline Mean & 0.977 & 0.976 & 0.991 & 1.000 & 0.987 & 0.987 & 0.981 & 0.976 & 0.965 & 1.00 & 0.981 & 0.986 \\
\hline Sd & 0.032 & 0.022 & 0.018 & ---- & 0.023 & 0.024 & 0.026 & 0.020 & 0.021 & 1.00 & 0.034 & 0.027 \\
\hline
\end{tabular}

The variation in solidity within species $(\mathrm{LSD}=0.267)$ was minimal and all values exceeded 0.9 at 0.05 a level. En.faecium and L.cremoris convex areas perfectly matched their shapes' area. Means solidity did not differ from the maximum or minimum values as the range was narrow fall around 1 .

Bacterial cells compactness

Compactness is a measure expressing how compact a feature is. Bacterial cells of lactic acid were compacted with a value close to 1 . The highest compactness $(0.979)$ was noticed with Pedi.acidilact in broth medium and the maximum mean compactness of $0.897 \pm 0.044$ in milk medium which indicated more compacted cells than the other species (Table 9). The minimum value was 0.699 for En.faecium in milk media. 
Table 9 . Maximum, minimum and average compactness of cocci lactic acid bacteria

\begin{tabular}{|c|c|c|c|c|c|c|c|c|c|c|c|c|}
\hline \multirow[t]{2}{*}{ Compactness } & \multicolumn{2}{|c|}{ En.faecalius } & \multicolumn{2}{|c|}{ En.faecium } & \multicolumn{2}{|c|}{ St.thermophilus } & \multicolumn{2}{|c|}{ L.s lactis } & \multicolumn{2}{|c|}{ L.cremoris } & \multicolumn{2}{|c|}{ Pedi.acidilact } \\
\hline & $B \mathbf{m}^{1}$ & $\mathrm{Mm}^{2}$ & $\mathrm{~B}$ m & $\mathrm{Mm}$ & B m & $\mathbf{M m}$ & $\mathrm{B} \mathbf{m}$ & Mm & $\mathrm{B} \mathrm{m}$ & $\mathrm{Mm}$ & B m & Mm \\
\hline Maximum & 0.953 & 0.976 & 0.846 & 0.893 & 0.842 & 0.940 & 0.978 & 0.935 & 0.976 & 0.953 & 0.979 & 0.945 \\
\hline Minimum & 0.774 & 0.732 & 0.754 & 0.699 & 0.741 & 0.791 & 0.814 & 0.784 & 0.799 & 0.832 & 0.799 & 0.841 \\
\hline Mean & 0.844 & 0.807 & 0.803 & 0.821 & 0.798 & 0.856 & 0.891 & 0.857 & 0.848 & 0.875 & 0.854 & 0.897 \\
\hline Sd & 0.055 & 0.077 & 0.038 & 0.085 & 0.036 & 0.041 & 0.053 & 0.049 & 0.061 & 0.049 & 0.061 & 0.044 \\
\hline
\end{tabular}

$\mathrm{B} \mathrm{m}^{1}$ : Broth media $\mathrm{Mm}^{2}$ : Milk media, LSD=0.046,

No significant differences were found between St.thermophilus in milk medium, L.s lactis and L.cremoris in both broth and milk media (LSD= $0.046, \alpha=0.05$ ) however Species of the bacterial cells significantly affected the cells compactness $(P<0.05)$, while type of media the bacteria grown in insignificantly influenced the cells compactness.

\section{0-Bacterial cells roughness}

In order to quantify the surface irregularities of the bacterial cells, surface topography roughness was characterized and quantified through the observations made by scanning electron microscopy (SEM). Several images were measured for each sample. Micrographs were recorded at different sample positions. As observed in the SEM surface micrographs (Fig.1and 2), the surface of the cell is practically non smooth, with irregularities. The amplitude properties are described by six parameters, which give information about the statistical average properties, the shape of the height distribution histogram and about extreme properties. All the parameters are based on two-dimensional standards that are extended to three dimensions.

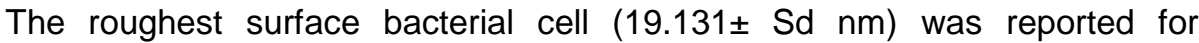
En.faecium in broth medium, while the smoothest was found with L. lactis $(12.064 \pm \mathrm{Sd} \mathrm{nm})$ as showen in fig3. No significant differences were found between St.thermophilus in milk medium, L.s lactis and L.cremoris in both broth and milk media $(L S D=0.046, \alpha=0.05)$ but Significant differences $(P<0.001)$ were found between bacterial strains in roughness as influenced by strain and media type

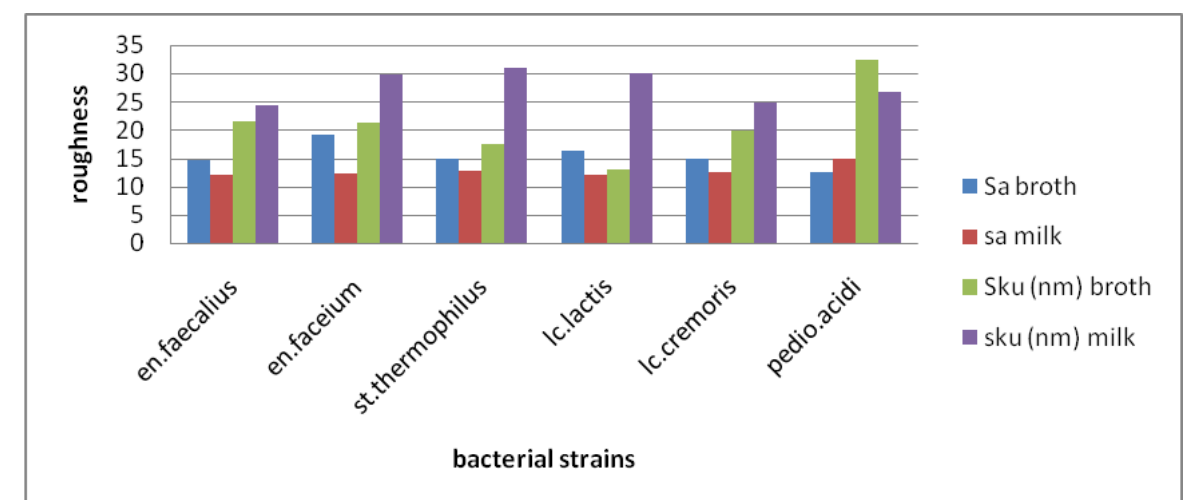

Fig (3).The average roughness Sa and surface kurtosis Sku in both broth and milk media for cocci strains of lactic acid bacteria. 
The Surface Kurtosis, Sku, describes the "peakedness" of the surface topography

The surface structure of the bacterial cells is somewhat rough and irregular. The external boundary was either a sharp outline or a rough surface, from one cell to another. The surfaces of the cells seem to have heights or extrudes, in rough cells.

Peakedness showed the highest value with Pedi.acidilact bacterial cell $(32.367 \pm \mathrm{Sd} \mathrm{nm})$ for En.faecium, while the lowest was reported with L.S lactis $(13.10 \pm \mathrm{Sd} \mathrm{nm})$ in broth medium as shown in Fig.3. Milk could be an inhibitor for peakedness. Analysis of variance (Table 28) for bacterial cells Roughness Sku (nm) showed significant influence of bacterial species and type of media and the interaction between the two factors $(P<0.001)$.

\section{1- Bacterial cells hardness}

Hardness was measured by the same system. The Hardness Analysis utilities are based on tests where the imprint created by an indenter is analyzed and quantified

The displacement where the indenter has maximum contact with the surface while unloading is denoted Contact Hardness

Contact Hardness $(\mathrm{hc})=\mathrm{F} / \mathrm{As}$ where: $\mathrm{F}$ is the maximum load force measured in Newton and As is the contact area when the displacement equals hc. The Force should be entered as the maximum load force measured in $\mathrm{mN}$

Lc. lactis had the maximum hardness $(50484 \mathrm{mN})$ in broth medium while, it had the lowest $(1284.6 \mathrm{mN})$ in milk medium which indicated that milk affected the hardness of this microorganism. The Grand Mean of 16668.994 was obtained for hardness of the spherical particles of bacterial cells.

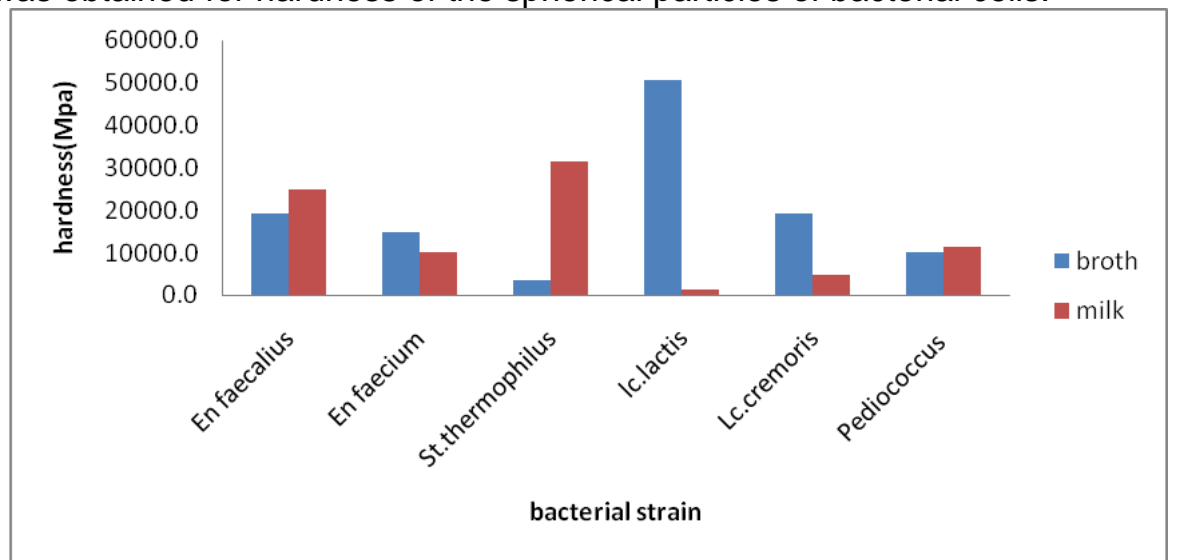

Figure 4. The average hardness in both broth and milk media for cocci strains of lactic acid bacteria

Significant differences were found within microorganisms (LSD value $=0.9203$ ) in hardness as a result of media type. All cocci lactic acid bacteria were significantly $(\mathrm{P}<0.001)$ affected by strains and type of media, in addition to the interaction between the two factors. 


\section{2-Bacterial cells' wall thickness}

Table 10. Maximum, minimum and average Wall thickness (um) of cocci lactic acid bacteria

\begin{tabular}{|c|c|c|c|c|c|c|c|c|c|c|c|c|}
\hline \multirow{2}{*}{$\begin{array}{l}\text { Wall } \\
\text { thickneaa }\end{array}$} & \multicolumn{2}{|c|}{ En.faecalius } & \multicolumn{2}{|c|}{ En.faecium } & \multicolumn{2}{|c|}{ St.thermophilus } & \multicolumn{2}{|c|}{ L.s lactis } & \multicolumn{2}{|c|}{ L.cremoris } & \multicolumn{2}{|c|}{ Pedi.acidilact } \\
\hline & B $\mathrm{m}^{1}$ & $\mathrm{Mm}^{2}$ & B m & $\mathrm{Mm}$ & B m & Mm & B m & Mm & B m & Mm & B m & Mm \\
\hline & 0.330 & 0.256 & & & & 0.240 & & & & & & \\
\hline & 0.190 & 0.207 & 0.250 & 0.120 & 0.160 & 0.220 & 0.155 & 0.190 & 0.187 & 0.120 & 0.220 & 0.210 \\
\hline & 0.270 & 0.231 & & 0.157 & 0.240 & 0.230 & 0.215 & 0.253 & 0.271 & 0.243 & & 0.250 \\
\hline & 0.072 & 0.025 & 0.041 & 0.035 & 0.114 & 0.010 & 0.065 & 0.093 & 0.037 & 0.137 & 0.065 & 0.053 \\
\hline
\end{tabular}

B $\mathbf{~ m}^{1}$ : Broth media $\quad \mathrm{Mm}^{2}$ : Milk media , LSD=0.059, Coefficient of Variation =29.84\%

Milk medium reduced the wall thickness of En.faecalius, En.faecium, St.thermophilus and Pediacidilact on the contrary of L.S lactis and L.cremoris table (10) mean of cell wall thickness was rangedbetween $0.157 \mathrm{~mm}$ for En.faeciumin milk media and $0.292 \mathrm{~mm}$ for the same strain but in broth media

Table 11. The mean values of shape and size parameters of cocci lactic acid bacteria

\begin{tabular}{|c|c|c|c|c|c|c|c|c|c|c|c|c|}
\hline $\begin{array}{c}\text { Shape and } \\
\begin{array}{c}\text { size } \\
\text { parameters }\end{array}\end{array}$ & $\mathbf{B m}$ & $\mathbf{M m}$ & $\mathbf{B m}$ & $\mathbf{M m}$ & $\mathbf{B m}$ & $\mathbf{M m}$ & $\mathbf{B m}$ & $\mathbf{M m}$ & $\mathbf{B m}$ & $\mathbf{M m}$ & $\mathbf{B m}$ & $\mathbf{M m}$ \\
\hline Diameter(um) & 1.38 & 1.22 & 1.35 & 1.28 & 1.17 & 1.11 & 1.33 & 1.30 & 1.34 & 0.93 & 0.91 & 0.96 \\
\hline Breadth (um) & 1.20 & 1.22 & 1.11 & 1.05 & 0.98 & 0.98 & 1.20 & 1.17 & 1.16 & 0.81 & 0.73 & 0.87 \\
\hline Length(um) & 1.63 & 1.52 & 1.69 & 1.57 & 1.47 & 1.30 & 1.50 & 1.51 & 1.59 & 1.07 & 1.07 & 1.08 \\
\hline Perimeter(um) & 4.69 & 4.29 & 4.55 & 4.17 & 3.97 & 3.70 & 4.53 & 4.45 & 4.70 & 2.98 & 3.06 & 3.21 \\
\hline Area(um $\left.{ }^{2}\right)$ & 1.50 & 1.17 & 1.44 & 1.28 & 1.08 & 0.99 & 1.40 & 1.34 & 1.43 & 0.69 & 0.56 & 0.73 \\
\hline Volume(um $\left.{ }^{3}\right)$ & 1.29 & 1.05 & 1.36 & 1.11 & 0.82 & 1.07 & 1.37 & 0.84 & 1.70 & 0.49 & 0.38 & 0.51 \\
\hline Roundness & 0.72 & 0.66 & 0.65 & 0.68 & 0.64 & 0.74 & 0.80 & 0.74 & 0.72 & 0.77 & 0.73 & 0.81 \\
\hline Compactness & 0.84 & 0.81 & 0.80 & 0.82 & 0.80 & 0.86 & 0.89 & 0.86 & 0.85 & 0.88 & 0.85 & 0.90 \\
\hline
\end{tabular}

\section{Discussion}

Summarized data in table 11 present the mean values of shape and size parameters of examined strains of cocci LAB, from the results of diameter, breadth, length, perimeter, area and volume in broth medium bacterial strains can be arranged from the smallest and bigger sizeas the following; Pedi. acidilacta, St. thermophilus and then other four strains came near in size parameterswhich indicated that, bacterial species are significantly different in size. Consequently, Prescot et al., (1993) reported that, bacterial size and shape are useful and valuable characteristics used in the classifications of bacteria because morphological structural features are usually genetically stable and easy to study and analysis.

Cell diameter ranges in present study (table 11) were as the following; Enterococcus (1.22-1.38), Streptococcus (1.11-1.17), Lactococcus (0.931.34) and Pediococcus (0.91-0.96) $\mu \mathrm{m}$. In this respect other studies deduced that, cell size ranges were; Enterococcus (0.87-1.01), Streptococcus (1.071.21) and Lactococcus (0.75-0.95) $\mu \mathrm{m}$ (Kokkinos et al., 1998) and Pediococcus (0.36-1.43) $\mu \mathrm{m}$ (Simpson and Taguchi, 1995). There were clear 
differences among studies which may be due to use of different culture media and growth conditions.

In the next series of experiments, results in table 11 indicated that, except Pedi. acidilactia, cells of other strains were generally smaller when grown in milk media than in broth media in cell size parameters; diameter, breadth, length, perimeter, area and volume. In an effort to explain the reason for this observation, microorganisms adapted their features to cope with diverse environmental niches or conditions, therefore bacteria actively modify their size and shapes according to some temporary changes such as moving from one growth phase to another and responding to nutritional alterations because shape is a significant element in physiological adaptations (Young, 2006). Overall shape and size may be constrained response to growth conditions (Neidhardt et al., 1990). The current study suggest that, culture media, growth conditions and growth phase must be mentioned as effective factors with the size and shape of bacteria to be useful and valuable characteristics for identification and classification of bacteria strains.

Mean values of roundness ranged from 0.64 for St. thermophilus in broth medium to 0.81 for Pedi. acidilactia in milk medium. Also, compactness mean ranged between 0.80 for En. faecium and St. thermophilus in broth medium and 0.90 for Pedi. acidilactia in milk medium ( table 11), which indicated that, cells of cocci LAB are not perfect spherical cells. Moreover, Siefert and Fox (1998) mapped the basic shapes onto the prokaryotic phylogenetic tree and concluded that bacterial morphology exhibits a definite historical trend, most likely beginning with a filamentous or rod-shape cell. Therefore, Young (2006) deduced that morphology is significant, that it can be charted on an evolutionary scale and that the earliest derived and degenerate forms.

\section{CONCLUSION}

Cell shape and size parameters can be used for identification and classification of lactic acid bacteria using scanning electron microscope and image analysis technique, but culture media, growth conditions and growth phase must be determined as effective factors and standard conditions.

\section{ACKNOWLEDGMENTS}

We thank Faculty of agriculture Alexandria university and Cairo Mircen Microbiological Resources Center at Ain-Shams university in charge of the Lactic acid strains Collection and Prof doctor Sally for technical assistance with the SEM. 


\section{REFERENCES}

Collins, M. D.; Samelis, J.; Metaxopoulos, J. and Wallbanks, S. (1993). Taxonomic studies on some leuconostoc-like organisms from fermented sausages: description of a new genus Weissella for the Leuconostoc paramesenteroides group of species. Journal of Applied Microbiology. 75: 595-603.

Devriese, L. A. and Pot, B. (1995). The genus Enterococcus. In B. J. B. Wood and W. H. Holzapfel (eds.). The Genera of Lactic Acid Bacteria (pp. 125-163).London: Blackie Academic \& Professional

Hardie, J. M. and Whiley, R. A. (1995). The genus Streptococcus. In B. J. B. Wood and W. H. Holzapfel (eds.). The Genera of Lactic Acid Bacteria (pp. 55-58).Blackie Academic \& Professional, London

Karna1,B.K.L, Emata ,O.C. and Barraquio, V.L. (2007). Lactic Acid and Probiotic Bacteria from Fermented and Probiotic Dairy Products. Science Diliman, 19:2, 23-34.

Kokkinos, A.; Fasseas, C.; Eliopoulos, E. and Kalantzopoulos, G. 1998. Cell size of various lactic acid bacteria as determined by scanning electron microscope and image analysis. Lait, 78: 491-500.

Neidhardt, F. C.; Ingraham, J. L. and Schaechter, M. 1990. Physiology of the bacterial cell: a molecular approach, p. 442-462.

Prescott, L.M.; Harley, J.P.; Klein, D.A., (1996). Microbiology. Third Edition., pp. 390-414.

Schleifer, K.H (2009). Classification of Bacteria and Archaea: Past, present and ,Applied Microbiology 32: 533-542

Siefert, H. L. and Fox, G. E. 1998. Phylogenetic mapping of bacterial morphology. Microbiology. 144: 2803-2808.

Simpson, W. J. and Taguchi, H. (1995). The genus Pediococcus with notes on the genera Tetratogenococcus and Aerococcus. In B. J. B. Wood and W. H.

Holzapfel (eds.). The Genera of Lactic Acid Bacteria (pp. 125-163). Blackie Academic \& Professional, London.

Teuber, M. (1995). The genus Lactococcus. In B. J. B. Wood and W. H. Holzapfel (eds.). The Genera of Lactic Acid Bacteria (pp. 125-163). Blackie Academic\& Professional, London

Victoria, K and Claudia ,V(2013). Electron microscopy of pharmaceutical systems Micron. 44., (2013) 45-74.

Young, K. D. 2006. The selective value of bacterial shape. Microbiol. Mol. Biol. Rev., 70(3): 660-703. 
دراسة الثكل الظاهرى وتركيب السطح لبكتريـا حامض اللاكتيك الكرويـة باستخدام

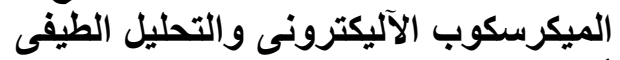

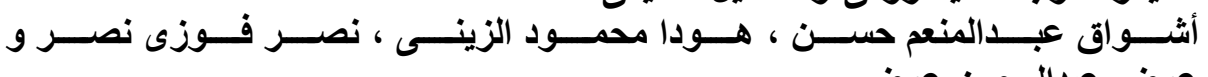

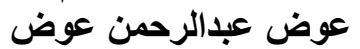
كلية الزراعة جامعة القاهرة

تنتشر بكتريا حامض اللاكتيك انتشـار ا كبير ا وتلعب دورا أساسيا وهامـا فى العديد

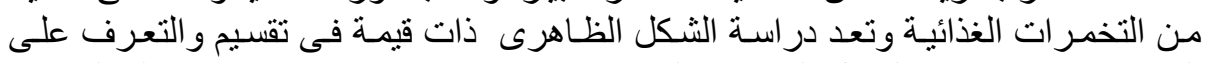

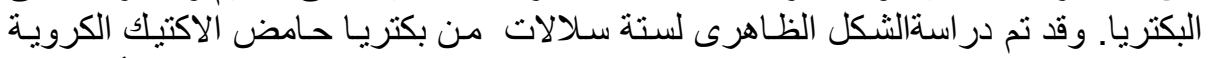

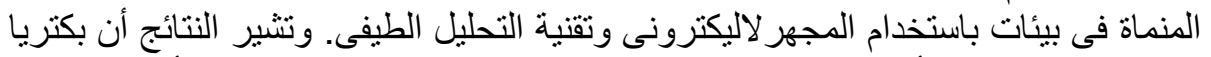

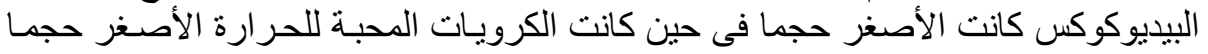
وبالمقارنة بالبيديوكوكس كانت الإنس

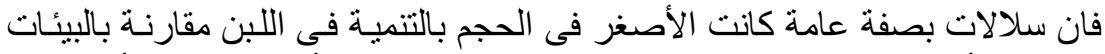

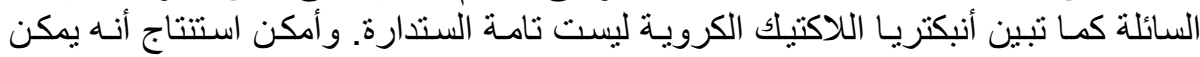

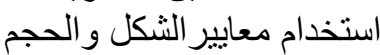
فى التعرف و التقسيم لبكتريا حامض اللاكتيك الكروية تحت ظروف نمو محددة, 